\title{
Differential response of protein metabolism in splanchnic organs and muscle to pectin feeding
}

\author{
Tatjana Pirman ${ }^{1 *}$, Laurent Mosoni ${ }^{2}$, Didier Rémond ${ }^{2}$, Marie Claude Ribeyre $^{2}$, Caroline Buffière ${ }^{2}$, \\ Janez Salobir ${ }^{1}$ and Philippe Patureau Mirand ${ }^{2}$ \\ ${ }^{1}$ Chair of Nutrition, Department of Animal Science, Biotechnical Faculty, University of Ljubljana, Groblje 3, Domžale SI-1230, \\ Slovenia \\ ${ }^{2}$ Unité Nutrition Humaine, INRA Clermont-Ferrand - Theix, Theix F-63122, France
}

(Received 22 May 2007 - Revised 23 October 2007 - Accepted 14 November 2007 - First published online 2 January 2008)

The aim of the present study was to determine whether the addition of soluble fibre in the diet affected protein metabolism in the intestinal tissues, some visceral organs and in skeletal muscle. A diet supplemented with pectin $(80 \mathrm{~g} / \mathrm{kg})$ was fed to young growing rats and the effect on organ mass and protein metabolism in liver, spleen, small and large intestines and gastrocnemius muscle was monitored and compared with the control group. Protein synthesis rates were determined by measuring $\left[{ }^{13} \mathrm{C}\right]$ valine incorporation in tissue protein. In the pectin-fed rats compared with the controls, DM intake and body weight gain were reduced (9 and $20 \%$, respectively) as well as gastrocnemius muscle, liver and spleen weights (6, 14 and $11 \%$, respectively), but the intestinal tissues were increased (64\%). In the intestinal tissues all protein metabolism parameters (protein and RNA content, protein synthesis rate and translational efficiency) were increased in the pectin group. In liver the translational efficiency was also increased, whereas its protein and RNA contents were reduced in the pectin group. In gastrocnemius muscle, protein content, fractional and absolute protein synthesis rates and translational efficiency were lower in the pectin group. The stimulation of protein turnover in intestines and liver by soluble fibre such as pectins could be one of the factors that explain the decrease in muscle turnover and whole-body growth rate.

Citrus pectin: Protein metabolism: Splanchnic tissues: Muscle

Dietary fibres are food components that have essential effects in digestion in humans and animals. Fibre affects large-bowel function, causing an increase in stool output, dilution of colonic contents, a faster rate of passage through the gut and changes in the colonic metabolism of minerals, $\mathrm{N}$ and bile $\operatorname{acids}^{(1)}$. Soluble dietary fibre, such as pectin, is not digested by endogenous enzymes but fermented in the large intestine. Colonic fermentation leads to the production of SCFA, which are used as an energy source by enterocytes. Both the high fermentation rate and high viscosity induced by soluble dietary fibre supplementation may be responsible for the observed stimulation of intestinal mucosal cell proliferation ${ }^{(2)}$.

Indeed pectin has been reported to have a trophic effect on the pancreas and intestine ${ }^{(3)}$, to stimulate intestinal cell proliferation and to increase brush-border membrane enzyme activities $^{(4)}$. It was also demonstrated that pectin supplementation increased the levels of plasma enteroglucagon (peptides derived from proglucagon processing by intestinal $\mathrm{L}$ cells) in rats $^{(4)}$, which is a humoral factor for intestinal mucosal growth ${ }^{(5)}$. In addition, dietary pectin has been shown to modulate immune function in the intestine ${ }^{(6,7)}$ and spleen $^{(7)}$, and also the hepatic metabolism of cholesterol ${ }^{(8)}$ and biliary acids $^{(9)}$. This may have consequences for protein metabolism in these organs, but to our knowledge no data have been published about the effect of pectin on protein synthesis rate in intestinal tissues, except in our previous study ${ }^{(10)}$, or in other splanchnic or peripheral organs. Our hypothesis was that stimulation of protein metabolism in the intestines by pectin feeding could have consequences on protein metabolism in other organs.

Hence the present study was designed to evaluate the effect of citrus pectin on protein metabolism in the intestinal tissues, visceral organs and in skeletal muscles of growing rats, which were chosen as the animal model.

\section{Material and methods}

\section{Diets}

Two diets (Table 1) were prepared, the control diet and the $8 \%$ pectin diet in which a fraction of the wheat starch was replaced with pectin from citrus peel (Fluka reference no. 76280; degree of esterification 63-66\%; molecular weight 30000-100000 Da). The diets contained an oil mixture adjusted so that both diets were isoenergetic $(15 \cdot 3 \mathrm{~kJ} / \mathrm{g}$ metabolisable energy). The protein source of the diets was casein, purchased from Union des Caséineries de Charente Maritime (La Rochelle, France) and diets contained $110 \mathrm{~g}$

Abbreviation: MPO, myeloperoxidase.

* Corresponding author: Dr Tatjana Pirman, fax +38617241 005, email tatjana.pirman@bfro.uni-lj.si 
Table 1. Diets

\begin{tabular}{lcc}
\hline & Control & Pectin \\
\hline Ingredients $(\mathrm{g} / \mathrm{kg})$ & & \\
Casein & 120 & 120 \\
Wheat starch & 616 & 520 \\
Premix* & 40 & 40 \\
Sugar (sucrose) & 50 & 50 \\
Mixture of vegetable oils $†$ & 54 & 70 \\
Agar agar & 40 & 40 \\
Pectin & 0 & 80 \\
Mineral mixture & 70 & 70 \\
Vitamin mixture§ & 10 & 10 \\
Determined composition & & \\
DM (g/kg) & 901.54 & 906.69 \\
Crude protein (g/kg DM) & 118.89 & 116.67 \\
Crude fat (g/kg DM) & 60.20 & 78.33 \\
Crude ash (g/kg DM) & 49.58 & 51.49 \\
Calculated metabolisable energy content $(\mathrm{kJ} / \mathrm{g})$ & 15.3 & 15.3 \\
\hline
\end{tabular}

* Mixture of wheat starch and L-cystine $55 \mathrm{mg} / \mathrm{g}$ ( $2 \cdot 2 \mathrm{~g}$ cystine added in each diet).

† Rapeseed oil, groundnut oil and sunflower-seed oil (50:45:5, by vol.).

‡UAR 205 b (UAR, Villemoisson-sur-Orge, France).

crude protein per $\mathrm{kg}$. Diets were designed to meet the nutritional requirements of growing rats.

\section{Animals}

All procedures were in accordance with the guidelines formulated by the European Community for the use of experimental animals (L358-86/609/EEC). Twenty-four male weaning Sprague-Dawley rats $(60.96 \pm 2.68 \mathrm{~g}$ body mass $)$ from Charles River (Lyon, France) were housed in a ventilated room at a controlled temperature $\left(21^{\circ} \mathrm{C}\right)$ with a $12 \mathrm{~h}$ light-dark cycle (starting at 04.00 hours) and placed in individual cages with free access to drinking water. In the adaptation period (10d), the rats received commercial pellets ad libitum. After the adaptation period rats were separated into two identical groups; one received the control diet and the other the pectin diet. The experimental period lasted $14 \mathrm{~d}$. During the first week animals were pair-fed to avoid large differences in food intake induced by the food change with the pectin diet. They were fed ad libitum during the second week during which growth performance measurements were performed.

\section{Tissue sampling}

At the end of the experimental period, in vivo tissue protein synthesis rates were determined $17-20 \mathrm{~h}$ after the last daily food distribution by the flooding dose method ${ }^{(11)}$ using $\mathrm{L}-\left[{ }^{13} \mathrm{C}\right]$ valine $(150 \mu \mathrm{mol} / \mathrm{kg}, 50 \%$ enrichment; Euriso-Top, Saint Aubin, France). For each group, the basal enrichment of protein-bound valine in the tissues was determined in two rats. A flooding dose of $\left[{ }^{13} \mathrm{C}\right]$ valine was intravenously injected into the tail vein of the other ten rats of each group. At $15 \mathrm{~min}$ after $\left[{ }^{13} \mathrm{C}\right]$ valine injection the rats were anaesthetised by intraperitoneal injection of $0.3 \mathrm{ml}$ sodium pentobarbital. The abdominal wall was opened and rats were exsanguinated by sampling from the abdominal aorta with an EDTA-coated syringe $20 \mathrm{~min}$ after valine injection. Liver, spleen, gastrocnemius muscle, small intestine, caecum and colon were quickly excised and chilled on ice to stop tracer incorporation.

Stomach, small intestine and large intestine were quickly weighed with their contents, emptied, rinsed with a cold $2 \%$ TCA solution, wiped, put in labelled pre-weighed bags, weighed and frozen as soon as possible in liquid $\mathrm{N}_{2}$.

Simultaneously liver, spleen and gastrocnemius muscle from the right hind leg of the animals were quickly dissected. All samples were weighed, frozen in liquid $\mathrm{N}_{2}$ and kept at $-80^{\circ} \mathrm{C}$ until further analysis. The empty body mass was calculated from the difference between the body mass and the masses of the contents of the stomach, small and large intestine. As digestive contents have been reported to be increased by pectin feeding, this allowed us to calculate organ relative mass ( $\mathrm{g} / 100 \mathrm{~g}$ empty body mass) in order to detect changes in body composition more accurately.

\section{Protein metabolism measurements and analytical methods}

Protein synthesis activity was assessed by the absolute synthesis rate (ASR; mg/d) and translational efficiency, calculated as the amount of protein synthesised $(\mathrm{mg}) / \mathrm{d}$ per mg RNA:

$$
\mathrm{ASR}=\left(100 \times \frac{(\mathrm{EP}-\mathrm{EN})}{(\mathrm{EA} \times \mathrm{t})}\right) \times \operatorname{prot}
$$

where $\mathrm{t}$ is the incorporation time, $\mathrm{EP}$ is the ${ }^{13} \mathrm{C}$ enrichment of protein-bound valine at the time of death in the injected rats, EN is the natural enrichment of protein-bound valine, EA is the enrichment of tissue-free valine at the time of death in the injected rats and prot is the total tissue protein content. The $\left[{ }^{13} \mathrm{C}\right]$ valine enrichment in the free amino acid pool and in the protein pool of the tissues was measured as described elsewhere ${ }^{(12)}$, together with determination of the protein contents ${ }^{(13)}$, RNA contents ${ }^{(14)}$ and DNA contents ${ }^{(15)}$. Briefly, free valine enrichment determination was performed on 0.6 M-TCA extracts by GC-MS, with an HP 5972 organic mass spectrometer quadrupole coupled to an HP 5890 GC (Hewlett Packard, Les Ulis, France). Valine was measured as the tertiary butyl-dimethlsilyl derivative under electron impact ionisation. The ions $\mathrm{m} / \mathrm{z} 288$ and 289 were monitored by selective ion recording to determine the $\left[{ }^{13} \mathrm{C}\right]$ valine enrichment. For determination of the ${ }^{13} \mathrm{C}$ enrichment of protein-bound valine, tissue protein precipitates were hydrolysed in $6 \mathrm{M}$ $\mathrm{HCl}$. Valine was measured as $\mathrm{N}$-acetyl-propyl-amino acid as derivative. The ${ }^{13} \mathrm{CO}_{2}:{ }^{12} \mathrm{CO}_{2}$ ratio was determined with $\mathrm{GC}$ combustion isotope ratio MS (Isochrom; Fisons, Manchester, UK). Blood cell counts (leucocytes and erythrocytes) were determined with an automatic haematology counter (Minos; ABX, Montpellier, France). Myeloperoxidase (MPO) activity as a marker of neutrophil infiltration in tissues was assayed in the ileum according to the method of Krawisz et al. ${ }^{(16)}$.

\section{Statistical methods}

Results are presented as mean values and standard deviations. The number of rats was twelve per group except in tables with protein synthesis data because two rats per group were used to determine ${ }^{13} \mathrm{C}$ natural enrichment of protein-bound valine. The effect of the pectin diet was analysed using Student's $t$ test or the non-parametric Mann-Whitney test if variances were different (SAS Institute, Inc., Cary, NC, USA) ${ }^{(17)}$. 
Table 2. Effect of pectin feeding on animal body mass, dry matter intake and growth rate

(Mean values and standard deviations)

\begin{tabular}{|c|c|c|c|c|c|}
\hline & \multicolumn{2}{|c|}{ Control (n 12) } & \multicolumn{2}{|c|}{ Pectin (n 12) } & \multirow[b]{2}{*}{$P$} \\
\hline & Mean & SD & Mean & SD & \\
\hline Initial body mass (g) & $170 \cdot 0$ & $7 \cdot 9$ & $174 \cdot 3$ & $5 \cdot 2$ & 0.13 \\
\hline Final body mass $(\mathrm{g})$ & $227 \cdot 2$ & $14 \cdot 1$ & $220 \cdot 0$ & $10 \cdot 1$ & 0.17 \\
\hline DM intake $(\mathrm{g} / \mathrm{d})$ & $20 \cdot 42$ & $1 \cdot 20$ & $18 \cdot 53$ & 0.61 & $<0.001$ \\
\hline Growth rate $(\mathrm{g} / \mathrm{d})$ & 8.44 & 0.90 & $6 \cdot 75$ & 0.49 & $<0.001$ \\
\hline DM efficiency (\%) & $41 \cdot 32$ & $3 \cdot 23$ & $36 \cdot 48$ & 2.89 & $<0.001$ \\
\hline
\end{tabular}

\section{Results}

The effect of pectin on growth performance is given in Table 2 . DM intake, growth rate and DM efficiency (g body-weight gain/ $\mathrm{g}$ DM intake) were significantly lower in the pectin group than in the control group. No difference was detected in blood cell counts (not shown), except a significant increase $(P=0 \cdot 007)$ in the number of lymphocytes $\left(3.4(\mathrm{SD} 0.4) v .4 \cdot 2(\mathrm{SD} 0.6) \times 10^{3}\right.$ per $\mathrm{mm}^{3}$ in the control and pectin rats, respectively).

The effect of pectin feeding on organ mass is shown in Table 3. Supplementation of the diet with pectin significantly decreased the mass of gastrocnemius muscle and spleen $(P<0.05)$ and, to a lesser extent, of stomach $(P=0.053)$; nevertheless this corresponded to the decrease in body mass, since if these values are expressed as $\mathrm{g} / 100 \mathrm{~g}$ empty body mass the differences disappear. The mass of the liver was significantly decreased in the pectin group, irrespective of the mode of presentation of the results ( $\mathrm{g}$ or $\mathrm{g} / 100 \mathrm{~g}$ empty body mass). Intestinal tissues, small intestine and large intestine were significantly heavier in the pectin group. Differences were more pronounced in the small intestine $(+73 \%)$ than in the large intestine $(+34 \%)$. Similar differences were found when the values were expressed as $\mathrm{g} / 100 \mathrm{~g}$ empty body mass. In the ileum, MPO activity was low but significantly higher $(P=0.002)$ in the pectin-fed rats than in the control rats $(1.38$ (SD 0.73) $v$. 0.42 (SD $0 \cdot 16) \mathrm{U} / \mathrm{g}$ protein).

In gastrocnemius muscle, the absolute amount of protein and RNA was decreased (Table 4), as was its mass. The values for absolute protein synthesis rate (mg protein synthesised in the organ/d) and translational efficiency, which represents the mass of $\mathrm{mg}$ protein synthesised/d per $\mathrm{mg}$ RNA, were significantly decreased in the pectin group as compared with the control group. In the pectin group, they reached only 81 and $86 \%$ of the values in the control group, respectively. Fractional protein synthesis rates were similarly lower in the pectin group than in the control group (9.86 (SD 1.13) and 11.32 (SD 0.79); $P=0.007$ ).

Although the liver mass was lower in the pectin group than in the control group, the absolute amounts of protein and protein synthesis rates were not different in the two groups. However, the fractional protein synthesis was significantly higher $(P=0.011)$ in the pectin group than in the control group (71.31 (SD 7.29) and 58.45 (SD 11.28) \%/d, respectively). As RNA content was significantly decreased by pectin feeding $(-12 \%)$ (Table 5), translational efficiency was significantly increased $(+32 \%)$. The effects of pectin feeding in the spleen were similar to those in the liver but to a lesser extent, and only the decrease in RNA content $(-23 \%)$ was significant.

The largest effect of pectin feeding was found in intestinal tissues (Table 6), where all values were significantly increased by pectin feeding and to a similar extent in the small and large intestine. The absolute protein and RNA amounts, translational efficiency and absolute protein synthesis rates were increased by 54 and 57, 68 and 59, 32 and 35, 114 and $115 \%$, respectively in the small and large intestine. Consequently, the same effects were observed for the whole intestine.

\section{Discussion}

The present study confirms the trophic effect of pectin, a soluble dietary fibre, on intestinal tissues. Protein metabolism in

Table 3. Effect of pectin feeding on empty body and organ masses (Mean values and standard deviations)

\begin{tabular}{|c|c|c|c|c|c|}
\hline \multirow[b]{2}{*}{ Organs } & \multicolumn{2}{|c|}{ Control (n 12) } & \multicolumn{2}{|c|}{ Pectin ( $n$ 12) } & \multirow[b]{2}{*}{$P$} \\
\hline & Mean & SD & Mean & SD & \\
\hline \multicolumn{6}{|l|}{ Absolute organ mass (g) } \\
\hline Gastrocnemius muscle & $1 \cdot 268$ & 0.10 & $1 \cdot 190$ & 0.08 & 0.05 \\
\hline Liver & 11.54 & 1.68 & 9.90 & 0.68 & $<0.01$ \\
\hline Spleen & 0.682 & 0.047 & 0.605 & 0.109 & 0.05 \\
\hline Stomach & 1.99 & $0 \cdot 24$ & 1.77 & 0.29 & 0.05 \\
\hline Small intestine & $6 \cdot 30$ & 0.37 & $10 \cdot 90$ & 0.96 & $<0.001$ \\
\hline Large intestine & 1.97 & 0.27 & $2 \cdot 63$ & 0.29 & $<0.001$ \\
\hline Intestines & $8 \cdot 27$ & 0.59 & 13.53 & $1 \cdot 10$ & $<0.001$ \\
\hline \multicolumn{6}{|c|}{ Relative organ mass ( $\mathrm{g} / 100 \mathrm{~g}$ EBM) } \\
\hline 'Empty' body mass (g) & $216 \cdot 2$ & 11.9 & $204 \cdot 2$ & $8 \cdot 7$ & $<0.01$ \\
\hline Gastrocnemius muscle & 0.586 & 0.031 & 0.583 & 0.026 & 0.76 \\
\hline Liver & $5 \cdot 33$ & 0.64 & $4 \cdot 85$ & 0.28 & $<0.05$ \\
\hline Spleen & 0.316 & 0.029 & 0.296 & 0.049 & 0.23 \\
\hline Stomach & 0.929 & 0.161 & 0.865 & 0.140 & 0.32 \\
\hline Small intestine & 2.92 & 0.12 & $5 \cdot 35$ & 0.51 & $<0.001$ \\
\hline Large intestine & 0.908 & 0.09 & 1.289 & 0.141 & $<0.001$ \\
\hline Intestines & 3.82 & $0 \cdot 15$ & $6 \cdot 64$ & 0.58 & $<0.001$ \\
\hline
\end{tabular}

EBM, empty body mass (body mass without intestinal content). 
Table 4. Effect of pectin feeding on protein metabolism in gastrocnemius muscle

(Mean values and standard deviations)

\begin{tabular}{|c|c|c|c|c|c|}
\hline & \multicolumn{2}{|c|}{ Control (n 10) } & \multicolumn{2}{|c|}{ Pectin ( $n$ 10) } & \multirow[b]{2}{*}{$P$} \\
\hline & Mean & SD & Mean & SD & \\
\hline Protein (mg) & 239.8 & $17 \cdot 6$ & 218.9 & $10 \cdot 1$ & $<0.01$ \\
\hline RNA (mg) & $1 \cdot 76$ & 0.12 & 1.64 & 0.15 & $<0.05$ \\
\hline ASR (mg/d) & 27.06 & 1.87 & 21.83 & $2 \cdot 66$ & $<0.001$ \\
\hline $\begin{array}{l}\text { Translational } \\
\text { efficiency } \\
\text { (mg protein/mg } \\
\text { RNA per } \mathrm{d} \text { ) }\end{array}$ & $15 \cdot 44$ & $1 \cdot 16$ & $13 \cdot 23$ & 1.08 & $<0.001$ \\
\hline
\end{tabular}

ASR, absolute synthesis rate.

intestinal tissues and in the liver was significantly stimulated by pectin feeding, but, on the other hand, protein metabolism in gastrocnemius muscle was reduced. The effect of pectin in the spleen was low.

As expected, the most striking effect of pectin feeding was detected in the intestinal tissues, where the organ masses and their protein and RNA amounts were increased. Similar hypertrophy of gut tissues after consuming fibrous diets has been reported in rat $^{(18-20)}$ and pig ${ }^{(21)}$ studies. Fukunaga et al. ${ }^{(22)}$ have already demonstrated that pectin has a significant trophic effect on the ileum, caecum and colon in rats fed a diet supplemented with $2.5 \%$ pectin. In the present study, the hypertrophies in intestinal tissues were well marked in the small and large intestine. This corresponds to a stimulation of protein synthesis in all parts of the intestines. This is consistent with an increase of intestinal endogenous protein secretion and enterocyte renewal ${ }^{(23)}$. It could be attributed to a stimulated microflora activity. Bacterial fermentation of dietary fibre in the caecum and colon produces SCFA which in turn induce cell proliferation in the lower intestinal tract. Our previous results ${ }^{(10)}$ showed that the same pectin diet stimulated

Table 5. Effect of pectin feeding on protein metabolism in liver and spleen

(Mean values and standard deviations)

\begin{tabular}{|c|c|c|c|c|c|}
\hline & \multicolumn{2}{|c|}{ Control (n 10) } & \multicolumn{2}{|c|}{ Pectin (n 10) } & \multirow[b]{2}{*}{$P$} \\
\hline & Mean & SD & Mean & SD & \\
\hline \multicolumn{6}{|l|}{ Liver } \\
\hline Protein (mg) & 1899 & 228 & 1762 & 149 & 0.09 \\
\hline $\mathrm{RNA}(\mathrm{mg})$ & $86 \cdot 2$ & 6.5 & 76.4 & $6 \cdot 9$ & $<0.01$ \\
\hline $\mathrm{ASR}(\mathrm{mg} / \mathrm{d})$ & 1114 & 245 & 1276 & 153 & 0.11 \\
\hline $\begin{array}{l}\text { Translational } \\
\text { efficiency } \\
\text { (mg protein/mg } \\
\text { RNA per d) }\end{array}$ & $12 \cdot 80$ & $2 \cdot 78$ & $16 \cdot 92$ & $2 \cdot 70$ & $<0.01$ \\
\hline \multicolumn{6}{|l|}{ Spleen } \\
\hline Protein (mg) & $117 \cdot 3$ & 7.5 & $104 \cdot 9$ & $20 \cdot 5$ & 0.06 \\
\hline RNA (mg) & $5 \cdot 33$ & 0.66 & $4 \cdot 11$ & 0.84 & $<0.001$ \\
\hline ASR $(\mathrm{mg} / \mathrm{d})$ & $46 \cdot 15$ & 7.02 & 44.50 & $11 \cdot 18$ & 0.71 \\
\hline $\begin{array}{l}\text { Translational } \\
\text { efficiency } \\
\text { (mg protein/mg } \\
\text { RNA per d) }\end{array}$ & 8.97 & $1 \cdot 76$ & $10 \cdot 53$ & $1 \cdot 64$ & 0.06 \\
\hline
\end{tabular}

ASR, absolute synthesis rate.
Table 6. Effect of pectin feeding on protein metabolism in intestinal tissues

(Mean values and standard deviations)

\begin{tabular}{|c|c|c|c|c|c|}
\hline & \multicolumn{2}{|c|}{ Control (n 10) } & \multicolumn{2}{|c|}{ Pectin (n 10) } & \multirow[b]{2}{*}{$P$} \\
\hline & Mean & SD & Mean & SD & \\
\hline \multicolumn{6}{|l|}{ Small intestine } \\
\hline Protein $(\mathrm{mg})$ & 818 & 39 & 1263 & 108 & $<0.001$ \\
\hline RNA (mg) & 41.6 & 2.5 & $69 \cdot 8$ & $7 \cdot 7$ & $<0.001$ \\
\hline ASR $(\mathrm{mg} / \mathrm{d})$ & 632 & 156 & 1350 & 146 & $<0.001$ \\
\hline $\begin{array}{l}\text { Translational } \\
\text { efficiency } \\
\text { (mg protein/mg } \\
\text { RNA per d) }\end{array}$ & $14 \cdot 86$ & $3 \cdot 28$ & $19 \cdot 64$ & $2 \cdot 06$ & $<0.01$ \\
\hline \multicolumn{6}{|l|}{ Large intestine } \\
\hline Protein (mg) & 172 & 25 & 270 & 48 & $<0.001$ \\
\hline RNA (mg) & $5 \cdot 20$ & 0.80 & $8 \cdot 25$ & 2.03 & $<0.001$ \\
\hline ASR (mg/d) & $57 \cdot 3$ & $7 \cdot 8$ & $123 \cdot 2$ & $30 \cdot 1$ & $<0.001$ \\
\hline $\begin{array}{l}\text { Translational } \\
\text { efficiency } \\
\text { (mg protein/mg } \\
\text { RNA per d) }\end{array}$ & $11 \cdot 86$ & 1.71 & $16 \cdot 00$ & $2 \cdot 31$ & $<0.001$ \\
\hline \multicolumn{6}{|l|}{ Intestines } \\
\hline Protein (mg) & 990 & 51 & 1533 & 130 & $<0.001$ \\
\hline RNA (mg) & $46 \cdot 8$ & $2 \cdot 6$ & $69 \cdot 8$ & $7 \cdot 7$ & $<0.001$ \\
\hline ASR $(\mathrm{mg} / \mathrm{d})$ & 689 & 160 & 1473 & 165 & $<0.001$ \\
\hline $\begin{array}{l}\text { Translational } \\
\text { efficiency } \\
\text { (mg protein/mg } \\
\text { RNA per d) }\end{array}$ & 14.56 & $3 \cdot 10$ & 21.43 & $2 \cdot 35$ & $<0.001$ \\
\hline
\end{tabular}

ASR, absolute synthesis rate.

the production of caecal and especially colonic SCFA, namely acetic, propionic and butyric acids. SCFA are considered to be the major mediators that stimulate intestinal mucosal growth ${ }^{(24,25)}$. SCFA were also shown to increase glucagon-like peptide 2 secretion by intestinal tissues ${ }^{(26)}$, which is a potent growth factor for intestinal mucosa. This effect on glucagon-like peptide 2 secretion was already proven with pectin ${ }^{(22)}$ and some other dietary fibres ${ }^{(27,28)}$.

The stimulation of protein metabolism by pectin feeding in the liver (translational efficiency and fractional protein synthesis rates) had no effect on liver protein weight, suggesting either an increase in protein degradation and/or in protein exportation because most of the plasma proteins are synthesised in the liver. As the intestine is a major site for breakdown and clearance of plasma protein, it is likely that the increase in intestinal metabolism caused an increase in plasma protein degradation which could be compensated for by stimulation of their synthesis in the liver. Consistent with this assumption, a decrease in serum albumin levels was reported in rats fed a low-protein diet when pectin was added $^{(29)}$. Whether an increase in cholesterol synthesis ${ }^{(8)}$ and excretion of biliary salts in pectin-fed animals ${ }^{(9)}$ could also contribute to the observed increase in liver protein metabolism is not known.

A marked stimulation of both intestinal and hepatic protein synthesis has also been described in acute inflammation ${ }^{(30)}$. Because the effect of pectin feeding on protein synthesis in the spleen was only a slight increase in translational efficiency, this indicates that it did not induce an acute inflammation response. However, there were some parameters that could indicate a slight stimulation of the immune response: 
the tendency to an increase of translational efficiency in the spleen, the increase in lymphocyte number in the blood, and in MPO activity in the ileum. These results are consistent with data in the literature showing an increase in $\operatorname{IgA}$ in serum, and $\operatorname{IgA}$ and $\operatorname{IgG}$ in the spleen and mesenteric lymph node lymphocytes ${ }^{(6,7)}$. However, the slight difference in MPO activity could also result from a difference in total peroxidase activity induced by the increase in whole-intestine metabolic activity, since the method used is not strictly specific for MPO ${ }^{(16)}$.

In our earlier studies with legumes added in the diet, protein metabolism in gastrocnemius muscle was decreased, if there was an effect on body-weight gain ${ }^{(31)}$ and was almost unchanged if there was no difference in the body-weight gain $^{(32,33)}$, which is in accordance with results of the present study. Gastrocnemius muscle is sensitive to the nature of the nutrients derived from the $\operatorname{diet}^{(34)}$ and, as a fast-twitch oxidative glycolytic muscle, is a good indicator of the average response of whole skeletal muscle ${ }^{(35)}$. The lowering effect of pectin feeding on muscle protein synthesis is not likely to be induced by a difference in last food intake because protein synthesis was determined $6 \mathrm{~h}$ after the beginning of the light period, i.e. when rats were not active and $18 \mathrm{~h}$ after the time at which food was offered. Furthermore, last food intake was not different in the two groups (20.6 (SD 3.3) and 20.2 (SD 2.1) g DM in the control and the pectin groups, respectively). In addition, the low and equal amount of food left in the stomach at slaughter (8.3 (SD 4.5) and 9.2 (SD 1.7) $\%$ of the ingested amounts for the pectin-fed and control rats, respectively) indicates that the amount of nutrients submitted to intestinal digestion was not different at that time. However, $\mathrm{N}$ faecal losses, mainly of endogenous origin, are known to be increased in pectinenriched diets ${ }^{(36,37)}$, resulting in an increased amino acid loss. Despite similar intakes of nutrients, there may be differential nutrient availability at peripheral levels due to large uptakes at splanchnic levels because of protein synthesis stimulation and due to increased endogenous losses. This may help to explain the present effect of pectin on muscle protein synthesis. Low-protein diets can enhance such an effect. This increase in the alteration of food efficiency and protein efficiency ratio by pectins has already been shown with low-protein diets ${ }^{(38)}$. It may suggest an increase in specific or global amino acid requirements of young growing rats during this 2 -week period that could be considered as an adaptation period, as suggested by experiments in pigs fed wheat shorts-containing diets ${ }^{(39)}$.

Pectin feeding resulted in a specific pattern of protein metabolism activities in organs characterised by an increase in protein turnover, i.e. in intestines and in the liver, and a decrease in muscle. If there are increasing data that could explain the causes of these alterations in the intestines, these factors are still unknown for the other organs. Further studies are needed to determine what could be the impact of the probable stimulation of the immune function, because it was shown that muscle protein anabolism was lessened in the case of low-grade inflammation ${ }^{(40)}$. These modifications are considered to affect the partitioning of nutrients between organs. Stimulation of protein synthesis in splanchnic tissues could reduce nutrient availability in peripheral organs. Additional investigations are needed to discover whether this partitioning is implicated in the alteration of the betweenorgan metabolic pattern induced by pectin feeding.

\section{Acknowledgements}

The authors are grateful to Christian Lafarge for animal care and Anne Diot and Corine Pouyet for participation in tissue protein synthesis determination. The authors had no conflicts of interest. This research was supported by the Proteus Bilateral Programme between Slovenia (Slovenian Research Agency) and France (French Research Ministry).

The contribution of each author was as follows: T. P., conception and design, tissue sampling, data processing, drafting and revision of the manuscript; L. M. and D. R., conception and design, tissue sampling, revision of manuscript; M. C. R., protein synthesis rate determinations; C. B., design, tissue sampling, blood cell counts and MPO determinations, data processing; J. S., conception and design, tissue sampling, data processing, revision of manuscript; P. P. M., conception and design, animal experiment, tissue sampling and revision of manuscript.

\section{References}

1. Stephen AM \& Cummings JH (1980) Mechanism of action of dietary fibre in the human colon. Nature 284, 283-284.

2. Gee JM, Lee-Finglas W, Wortley GW \& Johnson IT (1996) Fermentable carbohydrate elevate plasma enteroglucagon but high viscosity is also necessary to stimulate small bowel mucosal cell proliferation in rats. $J$ Nutr 126, 373-379.

3. Bamba T, Sasaki M \& Hosoda S (1994) Enteroglucagon: a putative humoral factor inducing pancreatic hyperplasia after small bowel resection. Dig Dis Sci 39, 1532-1536.

4. Chun W, Bamba T \& Hosoda S (1989) Effect of pectin, a soluble dietary fiber, on functional and morphological parameters on the small intestine in rats. Digestion 42, 22-29.

5. Sasaki M, Fitzgerald AJ, Mandir N, Sasaki K, Wright NA \& Goodlad RA (2001) Glicentin, and active enteroglucagon, has a significant trophic role on the small intestine but not on the colon in the rat. Aliment Pharmacol Ther 15, 1681-1686.

6. Lim BO, Yamada K, Nonaka M, Kuramoto Y, Hung P \& Sugano M (1997) Dietrary fibers modulate indices of intestinal immune function in rats. J Nutr 127, 663-667.

7. Yamada K, Tokunaga Y, Ikeda A, Ohkura K, Mamiya S, Kaku S, Sugano M \& Tachibana H (1999) Dietary effect of guar gum and its partially hydrolyzed product on the lipid metabolism and immune function of Sprague-Dawley rats. Biosci Biotechnol Biochem 63, 2163-2167.

8. Hexberg S, Hexeberg E, Willumsen N \& Berge RK (1994) A study on lipid metabolism in heart and liver of cholesteroland pectin-fed rats. Br J Nutr 71, 181-192.

9. Ide T \& Horii M (1989) Predominant conjugation with glycine of biliary and lumen bile acids in rats fed on pectin. Br J Nutr 61, 545-557.

10. Pirman T, Ribeyre MC, Mosoni L, Rémond D, Vrecl M, Salobir J \& Patureau Mirand P (2007) Dietary pectin stimulates protein metabolism in the digestive tract. Nutrition 23, 69-75.

11. Garlick PJ, McNurlan MA \& Preedy VR (1980) A rapid and convenient technique for measuring the rate of protein synthesis in tissues by injection of $\left({ }^{3} \mathrm{H}\right)$ phenylalanine. Biochem $J$ 192, 719-723.

12. Arnal MA, Mosoni L, Dardevet D, Ribeyre MC, Bayle G, Prugnaud J \& Patureau Mirand P (2002) Pulse protein feeding 
pattern restores stimulation of muscle protein synthesis during the feeding period in old rats. J Nutr 132, 1002-1008.

13. Smith PK, Kroh RI, Hermanson GT, Mallia AK, Gartner FH, Provenzano MD, Fujimoto EK, Goeke NM, Olson BJ \& Klenk DC (1985) Measurement of protein using bicinchoninic acid. Anal Biochem 150, 76-85.

14. Manchester K \& Harris EJ (1968) Effect of denervation on the synthesis of ribonucleic and deoxyribonucleic acid in rat diaphragm muscle. Biochem J 108, 177-183.

15. Giles KW \& Myers A (1965) An improved diphenylamine method for the estimation of deoxyribonucleic acid. Nature 206, 93.

16. Krawisz JE, Sharon P \& Stenson FW (1984) Quantitative assay for acute intestinal inflammation based on myeloperoxidase activity - assessement of inflammation in rat and hamster models. Gastroenterology 187, 1344-1350.

17. SAS (2000) Statistical Analaysis Systems Institute SAS/STAT User's Guide: Statistics Release 8e. Cary, NC: SAS Institute, Inc.

18. Goodlad JS \& Mathers JC (1990) Large bowel fermentation in rats given diets containing raw peas (Pisum sativum). Br J Nutr 64, 569-587.

19. Hansen I, Bach Knudsen KE \& Eggum BO (1992) Gastrointestinal implications in the rat of wheat bran, oat bran and pea fibre. Br J Nutr 68, 451-462.

20. Zhao X, Jørgensen H \& Eggum BO (1995) The influence of dietary fibre on body composition, visceral organ weight, digestibility and energy balance in rats housed in different thermal environments. Br J Nutr 73, 687-699.

21. Jørgensen H, Zhao XQ \& Eggum BO (1996) The influence of dietary fibre and environmental temperature on the development of the gastrointestinal tract, digestibility, degree of fermentation in the hind-gut and energy metabolism in pigs. Br J Nutr 75, 365-378.

22. Fukunaga T, Sasaki M, Araki Y, Okamoto T, Yasuoka T, Tsujikawa T, Fujiyama Y \& Bamba T (2003) Effects of the soluble fibre pectin on intestinal cell proliferation, fecal short chain fatty acid production and microbial population. Digestion 67, 42-49.

23. Fairweather-Tait SJ, Gee JM \& Johnson IT (1983) The influence of cooked kidney beans (Phaseolus vulgaris) on intestinal cell turnover and faecal excretion in the rat. Br J Nutr 49, 303-312.

24. Sakata T \& Yajima T (1984) Influence of short chain fatty acids on the epithelial cell division of digestive tract. Q J Exp Physiol Cogn Med Sci 69, 639-648.

25. Johnson IT, Gee JM \& Brown JC (1988) Plasma enteroglucagon and small bowel cytokines in rats fed soluble nonstarch polysaccharides. Am J Clin Nutr 47, 1004-1007.

26. Burrin D, Guan X, Stoll B, Petersen YM \& Sangild PT (2003) Glucagon-like peptide 2, a key between nutrition and intestinal adaptation in neonates. $J$ Nutr 133, 3712-3716.

27. Reimer RA, Thomson ABR, Rajotte RV, Basu TK, Ooraikul B \& McBurney MI (1997) A physiological level of rhubarb fiber increases proglucagon gene expression and modulates intestinal glucose uptake in rats. $J$ Nutr 127, 1923-1928.

28. Nian M, Gu J, Irwin DM \& Drucker DJ (2002) Human glucagon gene promoter sequences regulating tissue-specific versus nutrient-regulated gene expression. Am J Physiol Regul Integr Comp Physiol 282, R173-R183.

29. Rotenberg S \& Jakobsen PE (1978) The effect of dietary pectin on lipid composition of blood, skeletal muscle and internal organs. J Nutr 108, 1384-1392.

30. Breuillé D, Arnal M, Rambourdin F, Bayle G, Levieux D \& Obled C (1998) Sustained modifications of protein metabolism in various tissues in a rat model of long-lasting sepsis. Clin Nutr 94, 413-423.

31. Pirman T, Combe E, Ribeyre MC, Prugnaud J, Stekar J \& Patureau Mirand P (2006) Differential effects of cooked beans and cooked lentils on protein metabolism in intestine and muscle in growing rats. Ann Nutr Metab 50, 197-205.

32. Pirman T, Combe E, Patureau Mirand P, Stekar J \& Orešnik A (2004) Differential effects of cooked common bean (Phaseolus vulgaris) and lentil (Lens esculenta puyensis) feeding on protein and nucleic acid contents in intestines, liver and muscles in rats. Ann Nutr Metab 48, 281-287.

33. Combe E, Pirman T, Stekar J, Houlier ML \& Patureau Mirand P (2004) Differential effect of lentil feeding on proteosynthesis rates in the large intestine, liver and muscle of rats. J Nutr Biochem 51, 12-17.

34. Frühbeck G, Villaro AC, Monreal I \& Santidrian S (1999) Hormone-related, muscle-specific changes in protein metabolism and fiber type profile after faba bean intake. J Appl Physiol 86, 852-859.

35. Waterlow JC, Garlick PJ \& Millward DJ (1978) Protein Turnover in Mammalian Tissues and in the Whole Body. Amsterdam, The Netherlands: North-Holland Publishing Company.

36. Pastuzewska B, Kowalczyk J \& Ochtabinska A (2000) Dietary carbohydrates affect caecal fermentation and modify nitrogen excretion patterns in rats. I. Studies with protein-free diets. Arch Tierernahr 53, 207-225.

37. Mosenthin R, Sauer WC \& Ahrens F (1994) Dietary pectin's effect on ileal and fecal amino acid digestibility and exocrine pancreatic secretions in growing pigs. J Nutr 124, 1222-1229.

38. Samman N, Medici C, Rossi A \& Farias AN (1993) Protein utilization in rats fed diets with graded amounts of proteins in the presence of pectin. Nutr Res 13, 59-69.

39. Libao-Mercado AJ, Yin Y, van Eys J \& de Lange CFM (2006) True ileal amino acid digestibility and endogenous ileal amino acid losses in growing pigs fed wheat shorts- or casein-based diets. J Anim Sci 84, 1351-1361.

40. Mercier S, Breuillé D, Mosoni L, Obled C \& Patureau Mirand P (2002) Chronic inflammation alters protein metabolism in several organs of adult rats. J Nutr 132, 1921-1928. 